\title{
DIVERSE ATTITUDES FOR WRITING ART HISTORIES OF KOREA: THE IMPACT OF THE COLONIAL PERIOD ON THE RESEARCH OF KOREAN ART
}

\author{
Beatrix Mecsi
}

\section{Introduction}

How the colonial intervention in Korea by Japan - another Asian nation- has changed and formed the discussion about art and art history in Korea? What was the impact of this colonial scholarship on later studies in Korean art history? These are the main questions I would like to clarify in this paper.

Writing about art of a certain region is always a very complex task modified by the position and interests of the investigator, who is not always coming from the same tradition the given art was produced in. This question was raised and problematized most notably by Edward Said (1936-2003) in his famous book 'Orientalism' published in 1978. ${ }^{1}$ His concerns mainly focussed on literature and the Middle East, but soon his ideas became to be applied in a much wider context, making a special way to talk not only about literature, but about fine arts, too. In his book he emphasised that the study of the 'Orient' cannot be thought about without its colonial context. ${ }^{2}$ Said's Orientalist notion was adopted and criticized by several scholars, but the important question remains: how can we write about art of a given culture? How art history writing was developed in Korea? What kind of ideas were behind the works? Who were the first scholars dealing with Korean art history as such? What were the first approaches in this field? This paper is an attempt to put together scholarship written about this topic and briefly summarize the diverse attempts of writing about art in Korea from the colonial period up to the 1980s.

If we look at art histories written during the Colonial Period (1910-1945) we can trace several different attitudes. This was showed for the first time by Park Soon-won who pointed out that not only the much criticized colonial attitude was present during that period, but we can find other voices as well. ${ }^{3}$ The Japanese funding and organizing many important archeological excavations in the territory of Korea was used to advance

«? Edward Said, “Orientalism”, Vintage Books, 1978, Hungarian Translation: Edward W. Said: Orientalizmus. Budapest: Európa Könyvkiadó, 2000.

2 Michael Hatt and Charlotte Klonk, "Art History: A Critical Introduction to Its Methods", Manchester and New York, Manchester University Press, 2006.

3 Soon-Won Park, "Colonial Inventions: Korean Art Histories Written by Japanese Scholars", "Establishing a Discipline: The Past, Present and Future of Korean Studies", Los Angeles, County Museum of Art, 2001, pp 14-26. 
the legitimacy and control the peninsula, which was quite different from the efforts of Koreans to invent their own histories - though the material they used was more or less the same, only the interpretation and the context of presentation was different.

The Japanese interest in Korean folk culture is also an important aspect of writing about Korean art and its impact and influence is still present in contemporary Korea. The Japanese interpreted and collected Korean folk crafts, and was searching for folk traditions to enrich modern life. ${ }^{4}$ This attempt can be connected to certain Japanese artistic circles and considearbly influenced the taste and collecting patterns of not only the Japanese, but later the Koreans who were not interested in this aspect before the appearance of Japanese scholars and collectors. We can see how the intentions, interests and viewpoints of the Japanese influenced and distorted the writings on art in Korea.

\section{Writing Art Histories of Korea}

\section{Origins of Korean Studies in Japan}

When we talk about writing art history of Korea, we should understand the way how the disciple of art history and Korean studies developed in East Asia. For Europeans it seems natural to speak about disciples like art history and ethnography since the nineteenth century, but it was not evident in East Asian cultures to approach art objects in a way to analyze them within certain boundaries. Writing about art in Korea was more like the ancient way of compilations of the names and works of famous artists and praising their achievements. ${ }^{5}$ There was no need for building up a structure for scientific investigation, which was entirely a Western method of looking at the world. This method was adopted by the Japanese in the end of the nineteenth century, when the Western disciplines of geography, geology, paleontology, archaeology, art history, physical anthropology and ethnography were imported to Japanese universities. The Tokyo University Department of History (1885) was the first in East Asia to teach East Asian Studies (Tòyō gaku), and students could study not only the classical Chinese historical literature, but the above mentioned Western disciplines as well. ${ }^{6}$ Intellectuals were aware of the rapidly changing role of Japan in East Asia, therefore fostering these studies also served the interest of future politics. Their research turned soon towards the Korean peninsula. ${ }^{7}$ The earliest academic studies of ancient Korea appeared in the first issues of the journals of the Shigaku zasshi and Tōyō gakuho, published by the Tokyo

4 Soon-Won Park, "Colonial Inventions: Korean Art Histories Written by Japanese Scholars", "Establishing a Discipline: The Past, Present and Future of Korean Studies", Los Angeles, County Museum of Art, 2001, pp 14-26.

5 Sun-pyo Hong, "O Sech'ang's Kŭnyŏk sŏhwa ching: A Cornerstone of Korean Art History." in "Establishing a Discipline: The Past, Present and Future of Korean Studies", Los Angeles, County Museum of Art, 2001:5-12.

6 Kōjirō Yoshikawa, “Tōyōgaku no sōshihatachi (The Founders of East Asian Studies)", Tokyo: Kodansha, 1976.

7 Hugh M Kang, "Images of Korean History" In "Traditional Korea: Theory and Practice, ed. Andrew Nahm, Kalamazoo, Western Michigan University 1974:1-28; Hyung Il Pai, "Constructing Korean Origins", A Critical Review of Archaeology, Historiography, and Racial Myth in Korean State-Formation Theories, Harvard University Asia Center, Harvard University Press, Cambridge, Massachusetts and London, 2000, pp 24. 
University Department of History, and the Jinruigaku zasshi, published by the Tōkyō jinrui gakkai (Tokyo Anthropological Association), throughout the late 1890s. ${ }^{8}$

\section{Archeology of Korea by the Japanese}

In the late nineteenth and early twentieth centuries Japan started to expand towards the continent which was indicated by the Sino-Japanese (1894-95) and Russo-Japanese (1904-1905) wars. The building of the South Manchurian Railway was the impetus behind archaeological surveys, excavations and ethnographical research on the northern parts of Korea, Manchuria and Northern China. ${ }^{9}$ Yagi Sōzaburō was the first archaeologist sent to Korea, but it was Sekino Tadashi (or Tadasu, 1868-1935) of the Tokyo University Department of Architecture whose contributions to the study of East Asian art and archaeology are the most remarkable. ${ }^{10}$

Figure 1: Sekino Tadashi (1868-1935)

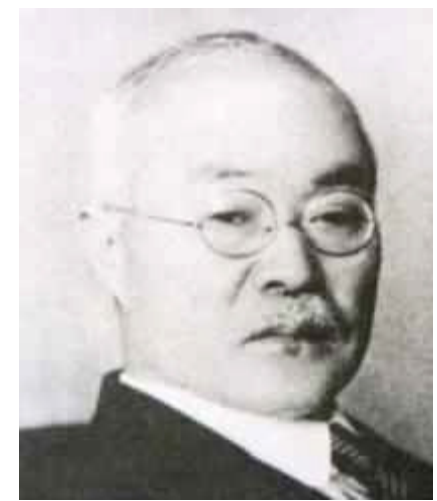

Source: hompi.sogang.ac.kr , accessed: 7 October 2012

Sekino Tadashi has spent only two months in Korea in 1902, but his report can be considered as the earliest work on Korean architecture and art history. ${ }^{11}$ He surveyed many buildings which have been destroyed by wars since that time, so his photographs are invaluable sources today. ${ }^{12}$ But it was not until 1910, the official annexiation of Korea

8 Hyung Il Pai, "Constructing Korean Origins", A Critical Review of Archaeology, Historiography, and Racial Myth in Korean State-Formation Theories, Harvard University Asia Center, Harvard University Press, Cambridge, Massachusetts and London, 2000, pp 24-25.

9 Ibid., pp $24-25$.

10 Tōkyō Daigaku sōgō kenkyū (Studies on Tokyo University Museum Collections), 1983.

11 関野, 貞 (Sekino Tadashi/or Tadasu), 韓国建築調査報告 (Kankoku kenchiku chōsa hōkoku-Report of the Korean Architetural Surveys), 東京: 東京帝国大学工科大学 (Tokyo: Tokyo Imperial University, Engineering Faculty: 1904; Hyung Il Pai, “Constructing Korean Origins", A Critical Review of Archaeology, Historiography, and Racial Myth in Korean StateFormation Theories, Harvard University Asia Center, Harvard University Press, Cambridge, Massachusetts and London, 2000, pp 25.

12 Hyung Il Pai, "Constructing Korean Origins", A Critical Review of Archaeology, Historiography, and Racial Myth in Korean State-Formation Theories, Harvard University Asia Center, Harvard University Press, Cambridge, Massachusetts and London, 2000, pp 25. 
to Japan, when the first systematic archeological surveys and excavations were carried out in Korea. ${ }^{13}$ And since that time the colonial archaeological service, Chōsen Koseki Chōsaka, of the Government-General of Korea became a powerful institution, receiving funds and institutional support from the Terauchi administration (1910-1916).$^{14}$ To protect the unruly treasure-hunting carried out by tomb-robbers, antique dealers and fortune seekers the Japanese Protectorate Government (Chōsen tōkanfu) established the Yi Royal Household Museum. ${ }^{15}$ Appoximately 12.000 pieces of art, mostly recently excavated blue-green glazed ceramics from the Goryeo period (918-1392) were bought back, preserved and displayed under official control. ${ }^{16}$

1916 was a crucial year in colonial administration, since the establishment of the state museum advanced legal control of art and archaeological policy. ${ }^{17}$ Museum branches opened in different cities, like in Gyeongju (1926), Pyeongyang (1930) and Gaeseong (1931), and Regulations on the Preservation of the Historical Remains (Chossen Koseki Oyobi Yuimosu Hozon Kisoku) was promulgated. The regulations prohibited the export of major Korean cultural properties and controlled the discovery, registration, display and publication of Korean treasures in the colonial state. ${ }^{18} 1916$ was the year, too, of the initiation of a grand publication project, the Illustrated Survey of Historical Remains in Korea (Chōsen Koseki Zūfü), which was ultimately completed in 1935 with 15 volumes althogether. ${ }^{19}$

Figure 2: Illustrated Survey of Historical Remains in Korea (Chōsen Koseki Zūfū)

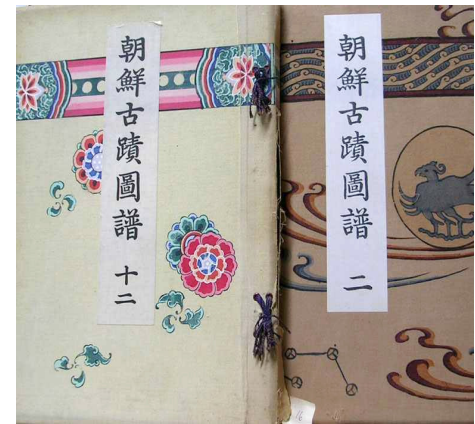

Source: hompi.sogang.ac.kr , accessed 7 October 2012.

In 1932 Sekino Tadashi has published his most influential writing about Korean art history entitled Art History of Korea (Chōsen Bijutsushi), which survives as one of the very few comprehensive art history books published in the colonial period.

How did the early art history and archaeology looked like in the first years of the colonial era? Using Benedict Anderson's words about colonial attitudes of these times,

\footnotetext{
13 Ibid., pp 25.

14 Soon-Won Park, “Colonial Inventions: Korean Art Histories Written by Japanese Scholars," in "Establishing a Discipline: The Past, Present and Future of Korean Studies", Los Angeles, County Museum of Art, 2001, pp 14-26.

15 Ibid., pp 16.

16 Ibid., pp 17.

17 Ibid., pp 17.

18 Ibid., pp 18.

19 Ibid., pp 18.
} 
it was an image of total surveyability, everything countable and serialized..$^{20}$ The foreword of Sekino's above mentioned book very much reflects the views of the colonial Japanese saying that

Ancient Korean art was influenced by Han Chinese in the Nangnang period, fluorished in the Silla period with its Tang (Chinese)-oriented Buddhist artistic culture, but started to decline in the Goryeo dynasty. The Yi (Joseon) period marked the final demise. In the present stage there is no artistic energy of any kind (in Korea). ${ }^{21}$

Following the European example, using scientific research was a tool in the hands of the Japanese, to use datas for justifying their presence in the colonized territories, however it was not the datas and facts, but their interpretation which was used and abused against the colonized. Narratives fabricated around this time still have their impact on common lores and even on scholarship, either this or the other way around.

Notions of the colonial racial sequence framework, that all artistic, cultural and technological changes were attributed to new arrivals and conquests by successive superior races who imposed their lifestyles and government on the Korean peninsula was used as a very important argument. ${ }^{22}$ According to this notion, in the case of Korea, from the very beginning, culture and technology was brought by the Northern Tungus nomads from Manchuria (bronze weapon-making skills), who were followed by Han Chinese who brought civilization by building cities, temples and introducing state formation, then finally the Japanese Wa occupied the southern part of the Korean peninsula (called Mimana by the Japanese) in the fourth-fifth centuries, and influenced the development of the Three Kingdoms. ${ }^{23}$ In this scheme connecting culture and race and imposing this framework, by which the conquerors were always pictured as more civilized, who bring enlightement and civilization, intended to prove the colonial subjects own general disability to change. ${ }^{24}$

The above mentioned foreword of Sekino's book on Korean art reflects also this sequential interpretation, regarding culture, showing a constant demise of Korean art towards the contemporary Joseon (Yi-dynasty) period. In this time, with Confucianism being the most important principle, as a heritage of traditional Chinese historiography, material culture also regarded less important compared to the continuing emphasis on written texts. It is still a regrettable fact, that in this period only inscriptions and texts were studied, abandoning the paintings and other objects containing those inscriptions. This practice and the continuous respect for the traditional Chinese historiography made many colonial interpreters labelling Korea as a mere follower of Chinese civilization,

20 Anderson, Benedict, Imagined Communities, Verso: London, 1991.

21 Tōkyō Daigaku sōgō kenkyū (Studies on Tokyo University Museum Collections), 1983; Park, Soon-Won, "Colonial Inventions: Korean Art Histories Written by Japanese Scholars." in Establishing a Discipline: The Past, Present and Future of Korean Studies, Los Angeles, County Museum of Art, 2001, pp 19.

22 Hyung Il Pai, "Constructing Korean" Origins, A Critical Review of Archaeology, Historiography, and Racial Myth in Korean State-Formation Theories. Harvard University Asia Center, Harvard University Press, Cambridge, Massachusetts, and London, 2000, pp 52.

23 Ibid., pp 52.

24 Ibid., pp 53; Trigger, Bruce, A History of Archaeological Thought. Cambridge: Cambridge University Press, 1989, pp 145. 
not being able to formulate its own unique culture (sadae: serving the bigger nation).$^{25}$ It is true, that even the most progressive and scientific scholars of the Joseon times did not regard material culture as valuable, and they even thought of some prehistoric remains as stone tools and arrowheads as made by nature and not by men. ${ }^{26}$ There was no interest in the past, except for those tombs which were used for royal ancestor worship..$^{27}$ Buddhist culture, and generally, the past was not interesting at all for the nobility and intelligentia of Joseon Korea, therefore it was the Japanese who exploited and initiated research introducing the new disciples and technology of archaeology and art history.

Ideas and statements like this had influenced the still prevailing view of Korean art as being seen as a mere bridge between Chinese and Japanese art, without having any particular specificity. In Korea, after the independence from Japan in 1945, and division in the aftermath of the Korean War, for more than half a century Korean studies were dominated by the school of nationalist hagiography (minjok sahak), reflecting anti-colonial resistance against Japanese imperialistic historical framework" (Ilchesagwan). ${ }^{28}$ For a long time, these scholars not only determined the direction of education in national history but also headed historical societies and cultural properties committees and directed cultural policies, as well as museum-building activities. ${ }^{29}$

As an obvious result of this approach and the struggles of getting rid of the remnants of the colonial era, it is still prevalent in Korea not to acknowledge the works of Japanese scholars, whose attitudes were more diverse than one could think. The historian Soon-Won Park (Howard University, Washington, DC) revealed these different attitudes with analyzing the works of the Japanese scholars written about Korean art and archaeology. ${ }^{30}$ She also pointed out how the movement for collecting ethnographical everyday objects from the countryside and appreciating them as art objects gave way

25 Hyung Il Pai, "Constructing Korean" Origins, A Critical Review of Archaeology, Historiography, and Racial Myth in Korean State-Formation Theories. Harvard University Asia Center, Harvard University Press, Cambridge, Massachusetts, and London, 2000, pp 96.

26 Ibid., pp 96; Choe Suk-gyeong, Gogohak seongnip ijeon eui yujeok yumul gwan (View of cultural relics and monuments before the establishment of archaeology)", in Kim Wonyong gyosu jeongnyeon toeim ginyeom nonjip (Commemorative essays in honor of Professor Kim Won-yong's retirement), Seoul: Ilchisa 1987, pp 750.

27 Hyung Il Pai, "Constructing Korean" Origins, A Critical Review of Archaeology, Historiography, and Racial Myth in Korean State-Formation Theories. Harvard University Asia Center, Harvard University Press, Cambridge, Massachusetts, and London, 2000, pp 96.

28 김용섭 Gim Yong-seop, 일본 한국에 있어서으한국사서술 Ilbon Hanguk e isseoseo eui Hanguksa seosul (Historical Writings about Korea in Korea and Japan), Yeoksa hakbo (Koren historical Journal, Seoul), 1966; Hanguk eui yeoksa insik (Historical Coinciousness in Korea), Seoul, Changjak gwa bipyeong, 1976; Minjok sahangnon eui panseong- Gwangbok samshimnyeon guksahak eui panseong gwa banghyang" (A reflection on thirty years of national historiography), Bundan shidae eui yeoksa insik (Historical Consciousness in a divided era), Seoul: Changjak gwa bipyeong 1978: 25-37; Hyung Il pai, Constructing "Korean Origins", A Critical Review of Archaeology, Historiography, and Racial Myth in Korean State-Formation Theories, Harvard University Asia Center, Harvard University Press, Cambridge, Massachusetts, and London, 2000, pp 1.

29 The Museum News, bound volume nos.1-300 July 1970-Aug.1996.

30 Soon-Won Park, "Colonial Inventions: Korean Art Histories Written by Japanese Scholars." in Establishing a Discipline: The Past, Present and Future of Korean Studies, Los Angeles, County Museum of Art, 2001, pp 15-25. 
to a movement not only in Korea, but also in Japan, and has changed the attitudes and interests of collectors until our days.

\section{The Admiration of Folk Traditions: The Mingei Movement}

Apart from the above mentioned colonial approach, there were other voices of Japanese scholars surveying Korean art and culture, and had different interests than the previously mentioned archaeologists and architects did. Unlike them, this other group of Japanese scholars found Joseon period white ceramics irresistably beautiful and posessing the unique essence of Korean artistic beauty. ${ }^{31}$ From the 1920s these scholars committed their lives to promote this artistic cause, collecting works of art and then established a privately funded museum, the Korean Folk Art Museum in 1924.

Yanagi Sōetsu (1889-1961), was a philosopher and an influential author, essayist and editor of several magazines, who turned towards Joseon folk art through the Asakawa brothers, Asakawa Noritaka (1885-1964) and Asakawa Takumi (1891-1931), who accompanied and guided him during his visits to Korea.

Figure 3: Yanagi Sōetsu (1889-1961)

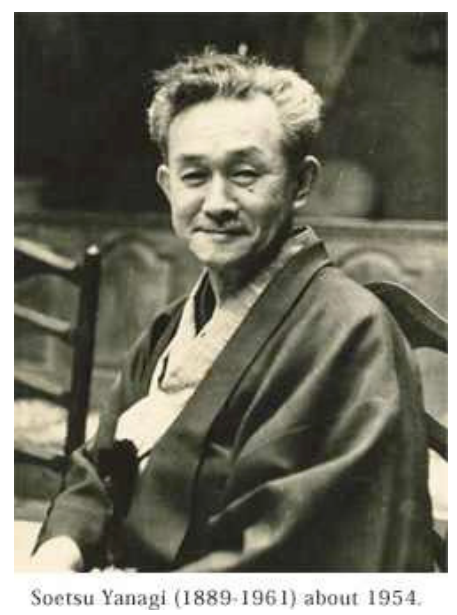

Source: mingeikan.or.jp, accessed 7 October 2012.

Together with their potter friends they founded the Mingei movement, where they put an emphasis on the admiration for the everyday objects made by unknown artisans, usually for everyday purposes (see Yanagi's famous book, The Unknown Craftsman, which was translated to English by his artist colleague, Bernard Leach). ${ }^{32}$ Their ideas rooted in the admiration of Korean folk art, but later they extended them to Japanese art too, and they founded the Japanese Folk Art Museum (Nihon Mingeikai), and influenced art collecting attitudes which still present in our days.

31 Ibid., pp 21.

32 Sōetsu Yanagi, "The Unknown Craftsman: A Japanese Insight into Beauty", Tokyo, New York, Kodansha International 1989. 
Yanagi has published several books and essays about Korean art, but the evaluation of his works are quite controversial. Later interpretors emphasise his famous notion about the sorrowful, melancholic beauty of Korean art, and they dismiss Yanagi's later observations and opinions. He criticized colonialism as a slavery based system, and the faulty attitudes of many Japanese scholars and collectors for their self-serving studies guided by Japanese needs and goals, and at the same time he noted a condescending, dualistic attitude among Japanese who were contemptuous of Korean artistic ability and aesthetics, though greedily collected Korean art. ${ }^{33}$ Yanagi and his Mingei movement promoted the connection between folk art and artisan traditions of the two countries, and attempted to surpass colonial prejudice against Korean art and initiated a new Korea-Japan joint art historical undertaking. ${ }^{34}$ However, Yanagi's contributions are not well received in Korea and the international literature also draws upon his earlier remarks about the 'sorrowful' nature of Korean art, thus putting him into the context of the colonial writers of Korean art history.

\section{The Impact of the Japanese Colonial Era on Later Scholarship}

From the 1930s young Korean archaeologists and art historians appeared on the sceene who enrolled in the Japanese-led universities, and specialized in archaeology and art history. The most famous Korean scholar of this type was Go Yuseop (1905-1944), who later became the director of the Museum in Gaeseong in 1933.

Figure 4: Go Yuseop (1905-1944)

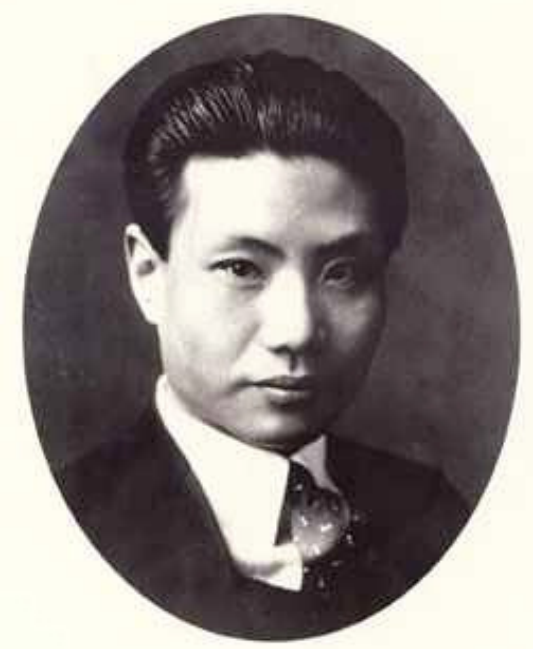

Source: koreanart21.com, accessed 7 October 2012.

33 Soon-Won Park, "Colonial Inventions: Korean Art Histories Written by Japanese Scholars." in Establishing a Discipline: The Past, Present and Future of Korean Studies, Los Angeles, County Museum of Art, 2001, pp 22.

34 Soon-Won Park, "Colonial Inventions: Korean Art Histories Written by Japanese Scholars." in Establishing a Discipline: The Past, Present and Future of Korean Studies, Los Angeles, County Museum of Art, 2001, pp 22. 
After 1945, when Korea was liberated from the colonial rule, the Japanese interest and collecting activities declined accordingly. The initial decades after independence were marked by strong anti-Japanese, nationalistic feelings that caused Koreans to ignore most of the works done by the Japanese in the field of art and archaeology, and for a long time they did not take any attempts to reevaluate them. ${ }^{\square}$ In extreme cases, any mention of Japanese art history written about Korean art was seen as unpatriotic. However, this self-imposed ignorance proved conterproductive to formulate a more objective scholarship, and it only happened in the 1980s when a new generation of art historians could distance themselves emotionally enough to formulate a different and critical view of revising and looking at and writing about their artistic tradition.

\section{Summary}

How the colonial intervention in Korea by Japan - another Asian nation- has changed and formed the discussion about art and art history in Korea? What was the impact of this colonial scholarship on recent studies in Korean art history? If we look at art histories written during the Colonial Period (1910-1945) we can trace several different attitudes. The Japanese funding and organizing many important archeological excavations in the territory of Korea was used to advance the legitimacy and control the peninsula, which was quite different from the efforts of Koreans to invent their own histories- though the material they used was more or less the same- only the interpretation and the context of presentation was different.

The Japanese interest in Korean folk culture is also an important aspect of writing about Korean art and its impact and influence is still present in contemporary Korea. The Japanese interpreted and collected Korean folk crafts, and was searching for folk traditions to enrich modern life. This attempt can be connected to certain Japanese artistic circles and considearbly influenced the taste and collecting patterns of not only the Japanese, but later the Koreans who didn't care much about this aspect before the appearance of Japanese scholars and collectors. Putting together the available literature, the paper showed how the intentions, interests and viewpoints of the Japanese influenced and distorted the writings on art in Korea. 
